\title{
CTHRC1 Gene
}

National Cancer Institute

\section{Source}

National Cancer Institute. CTHRC1 Gene. NCI Thesaurus. Code C112069.

This gene is involved in the cellular response to arterial injury. 